\title{
LOS ERRORES MÉDICOS
}

\author{
Fernando Sánchez Torres MD*
}

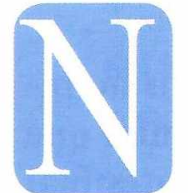

o hace mucho, la Organización Mundial de la Salud llamó la atención sobre la ocurrencia de "errores que matan", venidos del personal sanitario, especialmente de los médicos.

Esta preocupación no es nueva. Desde sus orígenes la Medicina Occidental se ha fundamentado en el sagrado principio moral de "no hacer daño" (primum non nocere). Sin embargo, sus cultores han sido y seguirán siendo seres humanos y, por lo mismo, susceptibles de cometer errores, lo que, por su gravedad, obliga a una preparación técnica y ética que sea prenda de garantía para quienes esperan beneficiarse de sus servicios.

Imposible establecer cuántas personas mueren anualmente por causa de errores médicos y menos cuántos errores no mortales se cometen. Muchos de esos deslices son intrascendentes, de ahí que pasen inadvertidos por los pacientes.

El manual de ética del Colegio Médico Norteamericano establece que el profesional debe revelar su error al paciente, si tal información va a redundar en beneficio de este. Pese a que no todos los errores médicos aparejan un componente antiético, al confesar su falta el facultativo queda expuesto a un proceso disciplinario y a otro civil o penal, lo cual lleva a que esas equivocaciones suelan quedar ocultas. De todas maneras, la certeza de que se cometió es un asunto que golpea anímicamente al médico de verdad responsable.

El error durante el acto médico puede presentarse en cualquiera de sus etapas: preventiva, diagnós-

Ex-rector de la Universidad Nacional. Ex-presidente del Tribunal Nacional de Ética Médica. Autor de varios libros sobre bioética y ética médica. tica y terapéutica, y puede juzgarse por acción o por omisión, imputable a impericia, imprudencia o negligencia. En esta ligera nota voy a referirme en particular al "error por impericia", que es algo que me atosiga desde hace unos cuantos años.

El ejercicio médico, en esencia, es un quehacer, vale decir, una cuestión de práctica. Aquel profesional que no se haya formado en la escuela del hacer carece de pericia para desempeñarse como tal $\mathrm{y}$, por lo tanto, es un médico proclive al error. Entre nosotros, no siempre ese factor ha sido tenido en cuenta por quienes conceden el diploma profesional.

Hay facultades de medicina que carecen de campos de entrenamiento - propios o prestados - donde sus estudiantes puedan adelantar las prácticas clínicas y quirúrgicas elementales. No obstante han venido otorgando títulos de idoneidad, dando con ello muestra de irresponsabilidad. Lanzar al mercado médicos carentes de habilidades propias de su profesión, es contribuir a que los "errores que matan" se acrecienten, pues no son garantía para la sociedad a la que pretenden servir.

El hecho de que los estudiantes de esos centros educativos eventualmente sean bien calificados en las pruebas de Estado, no autoriza para afirmar que estén bien preparados. Los 1lamados "ecaes" - o exámenes de conocimientos a cargo del Estado- son, para el caso que comento, un sofisma de distracción, una falacia educativa, que viene validando patentes de corso. Un aspirante a médico puede salir airoso en conocimiento teórico, pero si no ha tenido la oportunidad de "untarse bien de enfermo", está llamado al fracaso en el ejercicio práctico, es decir, va a ir de tumbo en tumbo, de error en error. 